\title{
Front Matter: Volume 6747
}

, "Front Matter: Volume 6747," Proc. SPIE 6747, Optics in Atmospheric Propagation and Adaptive Systems X, 674701 (4 December 2007); doi: 10.1117/12.782283

SPIE. Event: SPIE Remote Sensing, 2007, Florence, Italy 


\title{
PROCEEDINGS OF SPIE
}

\section{Optics in Atmospheric Propagation and Adaptive Systems $X$}

\author{
Karin Stein \\ Anton Kohnle \\ John D. Gonglewski \\ Editors
}

17-18 September 2007

Florence, Italy

Sponsored by

SPIE Europe

Cooperating Organisations

SPIE

EOS-European Optical Society

NASA-National Aeronautics and Space Administration (USA)

SIOF-Società Italiana di Ottica e Fotonica (Italy)

Published by

SPIE 
The papers included in this volume were part of the technical conference cited on the cover and title page. Papers were selected and subject to review by the editors and conference program committee. Some conference presentations may not be available for publication. The papers published in these proceedings reflect the work and thoughts of the authors and are published herein as submitted. The publisher is not responsible for the validity of the information or for any outcomes resulting from reliance thereon.

Please use the following format to cite material from this book:

Author(s), "Title of Paper," in Optics in Atmospheric Propagation and Adaptive Systems X, edited by Karin Stein, Anton Kohnle, John D. Gonglewski, Proceedings of SPIE Vol. 6747 (SPIE, Bellingham, WA, 2007) Article CID Number.

ISSN 0277-786X

ISBN 9780819469052

Published by

SPIE

P.O. Box 10, Bellingham, Washington $98227-0010$ USA

Telephone +1 3606763290 (Pacific Time) · Fax +1 3606471445

SPIE.org

Copyright (c) 2007, Society of Photo-Optical Instrumentation Engineers

Copying of material in this book for internal or personal use, or for the internal or personal use of specific clients, beyond the fair use provisions granted by the U.S. Copyright Law is authorized by SPIE subject to payment of copying fees. The Transactional Reporting Service base fee for this volume is $\$ 18.00$ per article (or portion thereof), which should be paid directly to the Copyright Clearance Center (CCC), 222 Rosewood Drive, Danvers, MA 01923. Payment may also be made electronically through CCC Online at copyright.com. Other copying for republication, resale, advertising or promotion, or any form of systematic or multiple reproduction of any material in this book is prohibited except with permission in writing from the publisher. The CCC fee code is $0277-786 \mathrm{X} / 07 / \$ 18.00$.

Printed in the United States of America.

Publication of record for individual papers is online in the SPIE Digital Library.

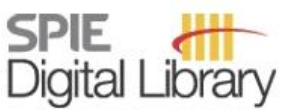

SPIEDigitalLibrary.org

Paper Numbering: Proceedings of SPIE follow an e-First publication model, with papers published first online and then in print and on CD-ROM. Papers are published as they are submitted and meet publication criteria. A unique, consistent, permanent citation identifier (CID) number is assigned to each article at the time of the first publication. Utilization of CIDs allows articles to be fully citable as soon they are published online, and connects the same identifier to all online, print, and electronic versions of the publication. SPIE uses a six-digit CID article numbering system in which:

- The first four digits correspond to the SPIE volume number.

- The last two digits indicate publication order within the volume using a Base 36 numbering system employing both numerals and letters. These two-number sets start with $00,01,02,03,04,05$, $06,07,08,09,0 \mathrm{~A}, 0 \mathrm{~B} \ldots \mathrm{OZ}$, followed by 10-1Z, 20-2Z, etc.

The CID number appears on each page of the manuscript. The complete citation is used on the first page, and an abbreviated version on subsequent pages. Numbers in the index correspond to the last two digits of the six-digit CID number. 


\section{Contents}

vii Conference Committee

\section{SESSION 1 PROPAGATION IN THE MARINE BOUNDARY LAYER}

674702 Millimeter-wave propagation over sea in tropical regions [6747-01]

H.-H. Fuchs, H. Essen, T. Brehm, Research Institute for High Frequency Physics and Radar Techniques (Germany); J. Förster, Federal Armed Forces Underwater Acoustics and Marine Geophysics Research Institute (Germany)

674703 Prediction of IR transmission in a coastal Baltic environment: comparison between model predictions and measurements [6747-02]

D. Dion, DRDC Valcartier (Canada); L. Gardenal, Nurun, Inc. (Canada); H. Vogel, DDRE (Denmark); L. Forand, DRDC Valcartier (Canada)

674704 Refraction effects under atmospheric stable conditions in coastal environments [6747-03] J. Claverie, CREC St-Cyr/LESTP \& IETR (France); D. Dion, DRDC Valcartier (Canada); K. Stein, FGAN-FOM (Germany)

674705 The SAPPHIRE trial: investigations on angular deviation caused by refraction [6747-04] K. Stein, D. Seiffer, FGAN-FOM (Germany)

674706 Measurements of IR propagation in the marine boundary layer in warm and humid atmospheric conditions [6747-05]

L. T. Heen, E. B. Madsen, P. Steenfeldt-Foss, K. Wikan, H. Fonnum, A. D. van Rheenen,

E. Brendhagen, B. Almklov, Norwegian Defence Research Establishment (Norway)

674707 Refraction measurements and modeling over the Chesapeake Bay during the NATO (TG51) SAPPHIRE trials, June 2006 [6747-06]

A. N. de Jong, P. J. Fritz, TNO-Defense, Security and Safety (Netherlands)

674708 Measurements of the vertical radiance profile using infrared sensors [6747-07]

A. D. van Rheenen, E. Brendhagen, L. T. Heen, E. B. Madsen, H. Fonnum, P. Steenfeldt-Foss,

K. Wikan, B. Almklov, Norwegian Defence Research Establishment (Norway)

674709 Measurements of the relative intensity of ship exhaust gas as a function of distance to infrared sensors [6747-08]

A. D. van Rheenen, E. Brendhagen, L. T. Heen, E. B. Madsen, H. Fonnum, P. Steenfeldt-Foss,

K. Wikan, B. Almklov, Norwegian Defense Research Establishment (Norway)

6747 OA The impact of boundary layer turbulence on optical propagation (Invited Paper) [6747-09] S. Cheinet, Institut Saint-Louis (France); A. P. Siebesma, Royal Netherlands Meteorological Institute (Netherlands) 
6747 OB Scintillation index of optical plane wave propagating through non-Kolmogorov moderatestrong turbulence [6747-10]

I. Toselli, Politecnico di Torino (Italy); L. C. Andrews, Univ. of Central Florida (USA);

R. L. Phillips, Univ. of Central Florida, Florida Space Institute (USA); V. Ferrero, Politecnico di Torino (Italy)

6747 OC Statistical turbulence vertical profiles at the Roque de los Muchachos Observatory and Teide Observatory [6747-11]

B. García-Lorenzo, J. J. Fuensalida, M. A. C. Rodríguez-Hernández, Instituto de Astrofísica de Canarias (Spain)

6747 OD Impact of turbulence on the measurement of CC\&D materials in desert area [6747-13] K. R. Weiss-Wrana, A. Malaplate, FGAN-FOM (Germany)

6747 OE Optimization of the mixing ratio of ice crystal shapes in cirrus clouds for atmospheric point spread function modeling [6747-14]

I. Muguet, P. Chervet, ONERA (France); C. Rozé, Univ. de Rouen (France)

\section{SESSION 3 ADAPTIVE SYSTEMS I}

6747 OG Shift estimation and non-uniformity in sequences of scene images [6747-15]

D. C. Dayton, Applied Technology Associates (USA); J. D. Gonglewski, C. St. Arnauld, Air Force Research Lab. (USA)

$6747 \mathrm{OH}$ Shack-Hartmann wavefront sensor using IR extended source [6747-16] C. Robert, B. Fleury, V. Michau, J.-M. Conan, L. Veyssiere, ONERA (France); S. Magli, L. Vial, Sofradir (France)

674701 Evaluations and progress in the development of an adaptive optics system for ground object observation [6747-17]

G. Marchi, R. Weiß, FGAN-FOM (Germany)

$67470 \mathrm{~J}$ Cross-wind profiling based on the scattered wave scintillations in a telescope focus [6747-19]

V. A. Banakh, D. A. Marakasov, Institute of Atmospheric Optics (Russia); M. A. Vorontsov, Army Research Lab. (USA)

6747 OK On the problem of beam focusing in the turbulent atmosphere [6747-18]

F. V. Shugaev, E. N. Terentiev, L. S. Shtemenko, O. A. Nikolaeva, T. A. Pavlova,

O. I. Dokukina, M.V. Lomonosov Moscow State Univ. (Russia)

\section{SESSION 4 ADAPTIVE SYSTEMS II}

6747 OM New LGS for large aperture telescope [6747-21]

V. Lukin, L. Bolbasova, Institute of Atmospheric Optics (Russia) and Tomsk State Univ. (Russia)

6747 ON Singular phase dynamics in vortical optical beam [6747-22]

O. V. Tikhomirova, V. P. Aksenov, Institute of Atmospheric Optics (Russia) 
6747 OP Wave front sensing of an optical vortex and its correction in the close-loop adaptive system with bimorph mirror [6747-32]

F. A. Starikov, Russian Federal Nuclear Ctr. -VNIIEF (Russia); V. P. Aksenov, Institute of Atmospheric Optics (Russia); V. V. Atuchin, Institute of Semiconductor Physics (Russia); I. V. Izmailov, F. Yu. Kanev, Institute of Atmospheric Optics (Russia); G. G. Kochemasov, Russian Federal Nuclear Ctr. -VNIIEF (Russia); A. V. Kudryashov, Adopt Ltd. and Moscow State Open Univ. (Russia); S. M. Kulikov, Russian Federal Nuclear Ctr. -VNIIEF (Russia);

Y. I. Malakhov, International Science and Technology Ctr. (Russia); A. N. Manachinsky,

N. V. Maslov, A. V. Ogorodnikov, Russian Federal Nuclear Ctr. -VNIIEF (Russia);

I. S. Soldatenkov, Institute of Semiconductor Physics (Russia); S. A. Sukharev, Russian Federal Nuclear Ctr. -VNIIEF (Russia)

\section{POSTER SESSION}

$67470 Q$ Determination of evaporation duct heights by an inverse method [6747-24]

R. Douvenot, V. Fabbro, ONERA (France); C. Bourlier, J. Saillard, Univ. de Nantes (France); H.-H. Fuchs, H. Essen, FGAN (Germany); J. Förster, Federal Armed Forces Underwater Acoustics and Marine Geophysics Research Institute (Germany)

6747 OR Forecast of optical turbulence in marine surface layer using numerical weather prediction products [6747-25]

Y. Li, F. Dai, Beijing Institute of Applied Physics and Computational Mathematics (China)

6747 OS Determination of turbulent-layer wind speed from G-SCIDAR data using an algorithm based on wavelet transforms [6747-26]

B. García-Lorenzo, J. J. Fuensalida, Instituto de Astrofísica de Canarias (Spain)

6747 OT Atmospheric turbulence profiling at the Teide Observatory: comparison and calibration of SODAR and SCIDAR measurements [6747-27]

A. de la Nuez Cruz, B. García-Lorenzo, J. J. Fuensalida, M. A. C. Rodríguez-Hernández, Instituto de Astrofísica de Canarias (Spain)

6747 OU Dome-seeing subtraction from G-SCIDAR measurements [6747-28]

J. J. Fuensalida, B. García-Lorenzo, C. Hoegemann, Instituto de Astrofísica de Canarias (Spain)

6747 OV Adaptive optics system prototype for the automatic control of geometrical fluctuations in a laser beam in air [6747-29]

S. Grasso, Univ. degli Studi di Roma Tre (Italy); F. Acernese, R. Romano, F. Barone, Univ. degli Studi di Salerno (Italy) and INFN Sezione di Napoli, Complesso Univ. di Monte S. Angelo (Italy)

6747 OW The hybrid Shack-Hartmann/G-SCIDAR instrument [6747-30]

M. A. C. Rodriguez Hernández, J. Jiménez-Fuensalida, B. M. García-Lorenzo, J. M. Delgado, E. Hernandez, C. Hoegemann, H. Vázquez Ramió, Instituto de Astrofísica de Canarias (Spain) 
6747 0X Measurements of transmission in the visible and the IR in the Baltic coastal environment [6747-31]

D. Dion, DRDC Valcartier (Canada); L. Gardenal, Nurun, Inc. (Canada); A. de Jong, TNODSS (Netherlands); H. Vogel, DDRE (Denmark); Y. Hurtaud, CELAR (France); K. Stein, FGANFOM (Germany); L. Forand, DRDC Valcartier (Canada)

Author Index 


\title{
Conference Committee
}

\author{
Symposium Chair \\ Guido D'Urso, Università degli Studi di Napoli Federico II (Italy) \\ Symposium Cochair
}

Steven P. Neeck, NASA Headquarters (USA)

Conference Chairs

Karin Stein, FGAN-FOM (Germany)

Anton Kohnle, FGAN-FOM (Germany)

John D. Gonglewski, Air Force Research Laboratory (USA)

Program Committee

David C. Dayton, Applied Technology Associates (USA)

Denis Dion, Defence Research and Development Canada-Valcartier (Canada)

Stephen M. Hammel, Space and Naval Warfare Systems Center, San Diego (USA)

Vladimir P. Lukin, Institute of Atmospheric Optics (Russia) and Tomsk

State University (Russia)

Sergio R. Restaino, Naval Research Laboratory (USA)

Jennifer C. Ricklin, DARPA/ATO (USA)

Marc J. F. Séchaud, ONERA (France)

Michael L. Shilko, Sr., ITT Industries, Inc. (USA)

Mikhail A. Vorontsov, Army Research Laboratory (USA)

Session Chairs

1 Propagation in the Marine Boundary Layer

Karin Stein, FGAN-FOM (Germany)

2 Propagation through Atmospheric Turbulence

Marc J. F. Séchaud, ONERA (France)

3 Adaptive Systems I

David C. Dayton, Applied Technology Associates (USA)

4 Adaptive Systems II

David C. Dayton, Applied Technology Associates (USA) 
Downloaded From: https://www.spiedigitallibrary.org/conference-proceedings-of-spie on 25 Apr 2023

Terms of Use: https://www.spiedigitallibrary.org/terms-of-use 